\title{
Anadolu Selçuklu Sanatında Kompozisyon-Derz İlişkisi
}

\author{
The Composition-Joint Relation in the Anatolian Seljuk Art
}

\author{
Mustafa Bulut \\ Dr., blt8@hotmail.com
}

\section{$\ddot{\mathbf{O} z}$}

Anadolu Selçuklu yapıları oluşturulurken; yapı tamamlanıp süslemenin sonradan yapıldığı veya öncelikli olarak süslemenin yapılıp taşların sonradan yerine konulduğu şeklinde farklı görüşler mevcuttur. Bu görüşleri desteklemek adına verilen örneklerin de genel olarak tek taraflı bakış açısıyla yapılmalarından kaynaklı eksikliklerinin olduğu söylenebilir. Bu nedenle konuya çok yönlü bir bakış açısıyla yaklaşarak yapım tekniği temelinde değerlendirme yapmak daha doğru sonuçlara ulaşılmasını sağlayacaktır.

Anadolu Selçuklu yapılarında süslemenin en fazla yapıldığı bölümlerin taç kapılar olduğu bilinmektedir. Bu nedenle de konuya öncelikli olarak taç kapılar bağlamında yaklaşılması önemlidir.

Yap1 tekniği olarak ifade edilebilecek bu görüşlerin ikisinin de uygulanabilirliği açıktır. Bu duruma karar verenin mimarın kendisinin olduğu söylenebilir. Daha kolay ve seri üretim açısından daha hızlı sonuçlara ulaşılabilecek tekniğin önce süslemenin yapılıp taşların sonradan yapıya monte edilmesi şeklinde olacağı bir gerçektir. Ancak bunun için de süslemenin kompozisyon-derz ilişkisi dediğimiz kompozisyon yüksekliğiyle taş blokların yüksekliğinin aynı olması şeklinde tanımlanabilecek tekniğin uygulanması gerekmektedir. Dolayısıyla kompozisyon-derz ilişkisini izleyebildiğimiz yapılarda süslemenin önce yapıldığı, bunun dışındaki yapılarda ise yapının önce yapılıp ardından süslemenin yapıldığı sonuçları çıkarılabilir. Bununla birlikte kompozisyon-derz ilişkisinin görüldügü yapıların bu ilişkinin görülmediği yapılara göre inşa tekniği açısından bazı hataları beraberinde getirdikleri söylenebilir.

Anahtar kelimeler: Anadolu Selçuklu, Taç Kapı, Ana Bordür, Kompozisyon-Derz İlişkisi, Yapı Tekniği

\section{Abstract}

While Anatolian Seljuk buildings were being constructed; there are different considerations such as the completion of the construction and subsequent made of the decorations or giving priority to the decoration and assemble it to the structure. It can be said that the examples given to support these views have deficiencies caused by being made up with unilateral perspective. For this reason, more accurate results will be achieved to evaluate the structure during the period in which it had been built by approaching the subject from a multi-faceted point of view.

The portals are known to be the most frequently decorated parts of the Anatolian Seljuk structures. For this reason, it is important to approach the subject firstly in the context of portals.

It is clear that both of these views, which can be expressed as building techniques, are also applicable. It can be said that the architect himself decides on this situation. It is a fact that the techniques that will provide faster results in terms of easier and serial production is giving priority to the decoration and assemble it to the structure afterwards. In order to achieve that it is necessary to apply the technique 
which can be defined as making the composition-joint relation of the decoration with the same height of composition height and height of stone blocks. Therefore, considering the results, it can be said that the decoration has previously been made on the constructions that we witness the composition-joint relation, and that the structure was made before for other constructions. However, comparing to the structures where the composition-joint relationship is seen, the structures in which this relationship is not seen have some errors in terms of the construction technique.

Keywords: Anatolian Seljuk, Portal, Main Rim, Composition-Joint Relation, Construction Technique

\section{Giriş}

Anadolu Selçuklu yapılarında taç kapılar gerek kütle ve hacimleri gerekse süslemeleriyle dikkati çekmektedir. Taç kapı yüzeyinin üç tarafı bordürlerle çevrelenmiş ve bu bordürlere çok çeşitli bezemeler yapılmıştır. Farklı büyüklükte tasarlanan bu bordürlerin en büyük ve en dikkat çekeni ana bordürdür. Bordürlere yapılan bezemelerde 13. yüzyıl ilk yarısına kadar geometrik süsleme kullanılırken, 13. yüzyıl ikinci yarısının başlarından itibaren geometrik ve bitkisel kompozisyonların birlikte kullanıldığı, sonlarına doğru ise bitkisel kompozisyonların tercih edildiği görülmektedir (Mülayim, 1982, s. 91).

Selçuklu sanatında kompozisyon-derz ilişkisi; bordürlerin tekrar eden en küçük birimi olan kompozisyon yüksekliğiyle kesme taşların yüksekliğinin aynı olması şeklinde tanımlanabilir. Yapılardaki kompozisyon-derz ilişkisi az sayıdaki araştırmacının dikkatini çekmiş ve bu ilişkiyi farklı şekillerde ifade etmişlerdir. Bu durumun bir yapı tekniği olabileceği ise Yıldıray Özbek tarafından dile getirilmiş̧ir. Özbek kompozisyon-derz ilişkisinin izlenebildiği yapılarda süslemenin önce yapılarak yapıya monte edildiğini belirtmiştir (Özbek, 2002, s. 32-34).

Selçuklu taç kapılarında kompozisyon-derz ilişkisi genel olarak iki eksenli sonsuz karakterli kompozisyonları barındıran ana bordürler üzerinden kurgulanmıştır. Bazı yapılarda bu ilişkinin iki, üç, hatta dört bordüre kadar devam ettirildiği görülebilir. Kompozisyon-derz ilişkisinin ana bordürlerde uygulanacağı yapılarda taş yükseklikleri her zaman aynı ölçülerde olacağından, taş ocaklarından taşların çıkarılmasından önce bu ilişkinin temel alınacağı kompozisyon veya kompozisyonların yapının tasarım aşamasında belirlenmiş olması gerekmektedir. Bazı yapılarda ise taş yükseklikleri aynı olmamakla birlikte kompozisyon-derz ilişkisi izlenebilmektedir. Ancak bu yapılarda bu ilişkinin olduğu kompozisyonlar silmeler ve taç kapı yüzeyinde kademe oluşturan iki eksenli sonsuz karakterli geometrik kompozisyonlar üzerinden kurgulanmıştır. Bu kompozisyonlarda taş yüksekliği eşit olmadığından kompozisyonları oluşturan düz çizgiler bazen uzun bazen de daha kısa yapılmış ve bu ilişki devam ettirilmiştir.

\section{Yöntem}

$\mathrm{Bu}$ çalışmada Betimsel araştırma yöntemi kullanılmıştır. Konuya ilişkin literatür taraması yapılmış, konu etraflıca tanımlanmaya çalışılmıştır. Örnekler ile karşılaştırmalı olarak ortaya konulmaya çalışılan bu araştırmada Olay-Vaka (Anekdot) Kaydı yöntemi ile konu araştırılmak üzere fotoğraf ve dökümanlar elde edilerek gözlemin objektif bir biçimde kaydedilmesi sağlanmıştır.

\section{Kompozisyon-Derz İlişsisinin Görüldüğü Yapılar}

İki eksenli sonsuz karakterli kompozisyonların kompozisyon-derz ilişkisi içerisinde değerlendirildiği ve kesme taş yüksekliklerinin aynı olduğu yapılarla tek eksenli sonsuz karakterli kompozisyonların kesme taş yüksekliklerinin eşit olmadan kompozisyon-derz ilişkisinin olduğu yapılar ve özellikleri şu şekilde siralanabilir: 
Divriği Kale Camii (1180) taç kapısı ana bordürü kompozisyon-derz ilişkisi içerisinde yapılmış olmasına rağmen, ilk yapılardan biri olması nedeniyle bazı özelliklerin henüz gelişmediği anlaşılmaktadır. Bu ilişkinin olduğu ana bordürün taşları kare şeklinde verilmiş ve bu taşların üst üste veya yan yana yapılması sonucu bordürün sağ ve solundaki bordür ve silmelerle bağlantısı taç kap1 yüzeyinde sağlanamamıştır. Giriş açıklığının üzerindeki sivri kemer alınlığına yapılan kompozisyonun iki sırası da yine dört taş blokla kompozisyon-derz ilişkisi içerisinde yapılmıştır. Ancak üçüncü sırada kompozisyon bütünlüğü bozulmadan üç taş blokla kompozisyon-derz ilişkisi dışında tamamlanmıştır (Görsel 1).

Tercan Mama Hatun Türbesi (1192-1202) taç kapısında ana bordürde kullanılan taşların artık yandaki bordür ve silmelerle küçük ölçekli de olsa girinti oluşturduğu, şaşırtmalı yapıldığı gözlenmektedir. Beşgen-ongen kompozisyonların özelliği olarak söylenebilecek dikdörtgen içerisindeki tekrar eden bölümler (Görsel 2), üst bölümde bordür kalınlığının farklı olmasına neden olmuştur. Yapının taç kapı bölümünde büyük çaplı bir restorasyon yapıldığı görülebilir. Özgün durumuna sadık kalınarak yapıldığı düşünülürse ana bordürün üst bölümde, Divriği Sitte Melik Türbesi taç kapısında olduğu gibi iki kompozisyonlu olarak tasarlandığı görülür.

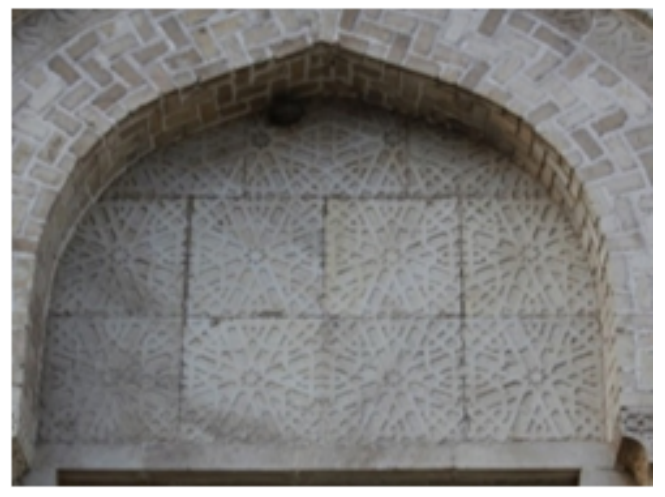

Görsel 1. Divriği Kale Camii taç kapı kemer alınlı̆̆ındaki kompozisyon-derz iliş̧kisi

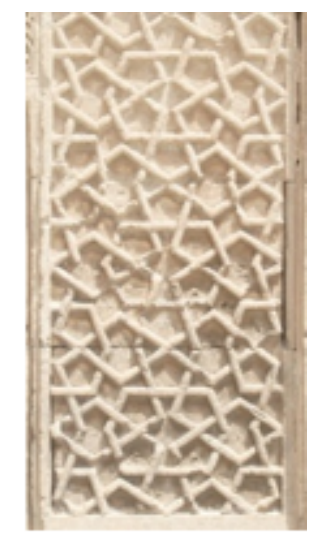

Görsel 2. Tercan Mama Hatun Türbesi taç kapı ana bordüründeki kompozisyon-derz ilişsisi

Kompozisyon-derz ilişkisinin görüldügü Kayseri Çifte Medrese (1205) taç kapısının ana bordürünün artık yanlardaki silme ve bordürlerle birlikte düşünüldüğü, bordür taşlarının bu bölümlere kadar uzanarak taç kap1 örgü taş1 şeklinde tasarlandığı görülmektedir. Bu durumun daha sağlam bir yap1 tasarımını ortaya çıkardığı açıktır ve bundan sonraki kompozisyon-derz ilişkili yapıların tasarımları bu şekilde yapılacaktır. Üst bölümü restorasyon sırasında yenilenen yapının ana bordürü yatayda özgün ölçüleriyle yapılmadığından ana bordür batıya doğru meyillidir. 
Kayseri Kölük Camii taç kapısında tek eksenli sonsuz karakterli altıgen açılara sahip süsleme her kesme taşa iki kompozisyon işlenecek şekilde yapılmıştır.

Amasya Hilafet Gazi Türbesi (1210) taç kapısının ana bordürü kompozisyon-derz ilişkisi içerisinde verilmesine rağmen kendi içerisinde düzensizdir. Şöyle ki; taş bloklar üzerine sürekli aynı kompozisyon çizilmiştir ancak bu kompozisyon çoğaltılma sınırları üzerinden hareket edilerek oluşturulmamıştır (Görsel 3, Çizim 1). Bu nedenle bordürdeki kompozisyonun birleşimi hatalıdır ve bu durumun restorasyon sonucu oluşmadığı rahatlıkla görülebilmektedir. Bu taç kapıda ayrıca belirtilmesi gereken nokta altıgen ve sekizgen açılara sahip silmenin de ana bordürle birlikte düşünülerek kompozisyon-derz ilişkisi içerisinde yapılmış olmasıdır.

Konya Hacı Ferruh Mescidi (1215) taç kapısının ana bordüründe iki farklı kompozisyon kullanılmıştır. Belirli bir yüksekliğe kadar ongen açılara sahip kompozisyon kullanılırken, devamında altıgen açılara sahip kompozisyon düzenlenmiştir (Çizim 2). Bununla birlikte harim kapısı ve mihrap ana bordürleri de taç kapı gibi kompozisyon-derz ilişkisi içerisinde tasarlanmıştır (Bakırer, 1969, s. 174; Tuncer, 1990, s. 232).

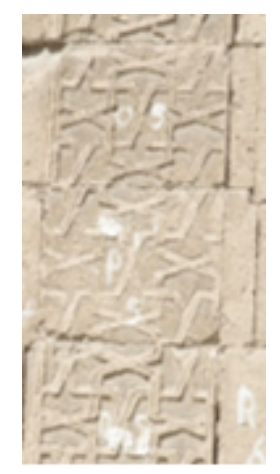

Görsel 3. Amasya Hilafet Gazi Türbesi taç kapı ana bordüründeki kompozisyonun düzensizliği

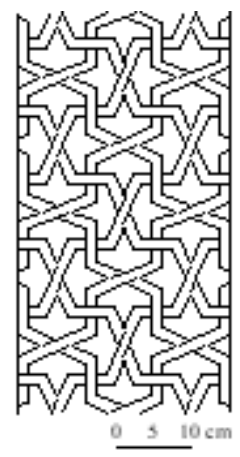

Çizim 1. Amasya Hilafet Gazi Türbesi taç kapı ana bordüründeki kompozisyonun olması gereken şekli
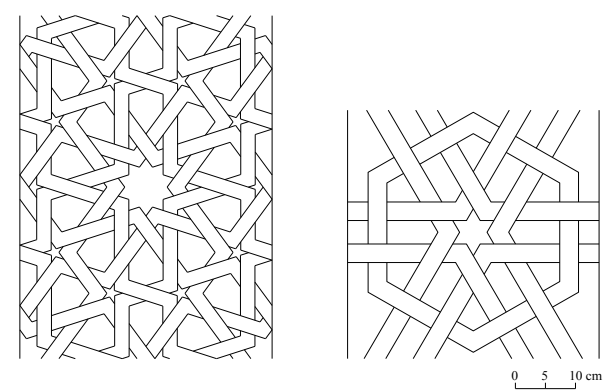

Çizim 2. Konya Hacı Ferruh Mescidi taç kapısı ana bordüründeki kompozisyonlar. 
Evdir Han (1215-19) taç kapısı ana bordürü kompozisyon-derz ilişkisi içerisinde yapılmıştır. Farklı olarak bazı taşlar dikine yerleştirildiğinden iki kompozisyon işlenmiştir.

Sivas İzzeddin Keykavus Şifahanesi (1217-18) taç kapısındaki iki geometrik süslemeli bordür de kompozisyon-derz ilişkisiyle yapılmıştır. Farklı olarak bu taç kapıda bordürlerin ikisi de oldukça enli bordürler olmasından dolayı kesme taşların şaşırtmalı yapılışını bozmamak adına düşeyde de kompozisyon-derz ilişkisi dikkate alınarak yapı tamamlanmıştır.

Niğde Alâeddin Camii (1223) taç kapı ana bordüründe de Konya Hacı Ferruh Mescidi taç kapısında olduğu gibi iki farklı kompozisyon kullanılmıştır. Alttaki kompozisyon tek taşta verilmiş ve kompozisyon-derz ilişkisi gözetilmemiştir. Üstteki kompozisyon alttakinin benzeri olmakla birlikte eklenen bazı elemanlarla farklılaştırılmıştır. Ana bordürle birlikte dış tarafindaki yarım dairelerden oluşan ve altıgen açıların kullanılarak oluşturulduğu tek eksenli sonsuz karakterli iki kompozisyon ile iç tarafindaki yine altıgen açıların kullanıldığı tek eksenli sonsuz karakterli bir kompozisyonu kapsayacak şekilde kompozisyon-derz ilişkisinin kullanılması, taç kapıda derz aralarıyla kompozisyonlar arasında inanılmaz bir ritmik tekrarın oluşmasını sağlamıştır (Görsel 4, Çizim 3). Taç kapıyı çevreleyen bu dört bordürün aynı kompozisyon-derz ilişkisi içerisinde verilmesi tasarımın başarısını göstermesi açısından önemlidir. Yapının kuzey taç kapısında da kompozisyon-derz ilişkisi iki bordürü kapsayacak şekilde verilmiştir. Ancak ana bordürün üst bölümüne Divriği Sitte Melik Türbesi ve Tercan Mama Hatun Türbesi taç kapısında olduğu gibi iki kompozisyon işlenmiştir.

Alay Han taç kapısında kompozisyon-derz ilişkisi ana bordür ve iki yanındaki diğer bordürleri de kapsamaktadır (Ögel, 1966, s. 7).

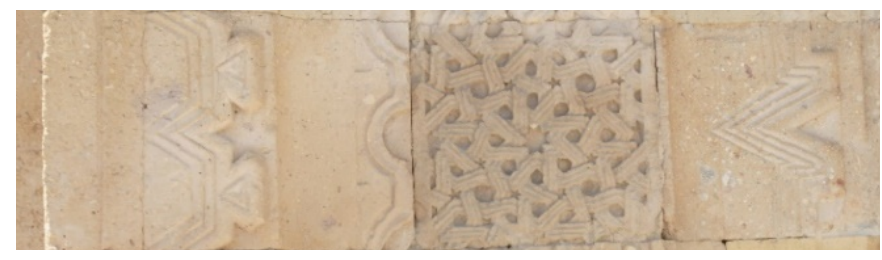

Görsel 4. Niğde Alâeddin Camii taç kapısında kompozisyon-derz ilişkisi içerisinde yapılan bordürler

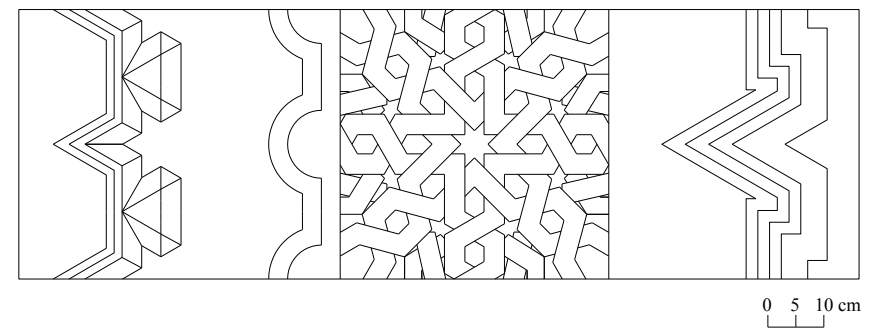

Çizim 3. Niğde Alaaddin Camii taç kapısında kompozisyon-derz ilişkisi içerisinde yapılan bordürler

Divriği Ulu Camii (1228) kuzey taç kapısı bu konuda ayrı bir öneme sahiptir. Taç kapıdaki ana bordür olarak nitelendirilebilecek birbirinden farklı özellikteki bitkisel kompozisyonların olduğu süslemelerin tamamı kompozisyon büyüklügüne göre bir veya iki kesme taşa işlenmiştir. Taç kapı kaidesinden başlayarak kavsarayı çevreleyen kemerin taşlarının da aynı özellikte yapıldığı söylenebilir. Taç kapının dış kenarlarındaki sekizgen kompozisyonlar da kesme taşlara tek veya ikili olarak düzenlenmişlerdir. Taç kapının birinci bordüründe yer yer görülebilen düzensizlik ve bağımsızlığın da yine bu bölümlerin kompozisyon-derz ilişkisi içerisinde yapılmasından kaynaklandığı söylenebilir. Aynı şekilde şifahane taç kapısının da süslemeleri, kavsara kemeri, kemer alınlığındaki beş köşeli yıldızlar, beşgenler ve baklava dilimleri de kompozisyon-derz ilişkisi içerisinde yapılmıştır. Divriği Ulu Camii doğu taç kapısının biri bitkisel diğeri geometrik olmak üzere iki bordürü vardır. Kompozisyon-derz ilişkisi de bu 
iki bordürü kapsayacak şekilde yapılmıştır (Görsel 5). Kavsara kemeri silmesiyle bordür arasındaki mesafenin üstte de devam ettirilmesi neticesinde, üstteki bordürün düşeydeki bordürlere göre biraz daha dar tutulması nedeniyle bordürün köşe birleşimi düzensiz olmuştur. Aynı şekilde bitkisel süslemeli bordürün de köşe dönüşünün olduğu taşın hemen altındaki taşa da yarım olarak bir kompozisyon işlenmiştir. Her ne kadar Divriği Ulu Camii için taşların yapı üzerinde oyulduğu söylense de (Kuban, 1999, s. 143; Kuban, 2010, s. 154) tespit edilen izler yerde oyulduktan sona taşların yapiya monte edildiklerini düşündürmektedir (Önge, 1978, s. 60).

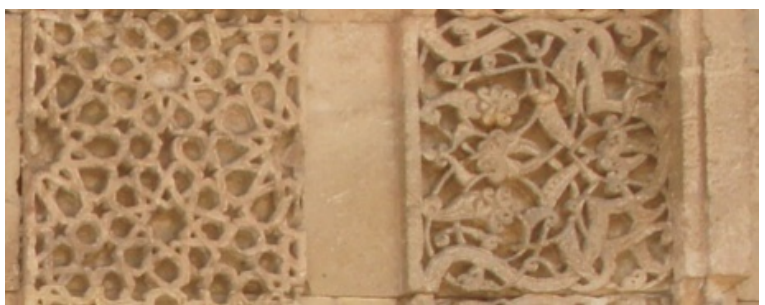

Görsel 5. Divriği Ulu Camii doğu taç kapısı kompozisyon-derz ilişkisi içerisinde yapılan bordürler

Aksaray Sultan Hanı avlu taç kapısında mukarnas frizi, palmet frizi ve zikzaklı süslemeye sahip köşe sütuncesi kompozisyon-derz ilişkisi içerisinde verilmiştir. Kesme taş yüksekliklerinin farklı olması nedeniyle bu üç süsleme taşlara farklı sayılarda işlenmiştir. Kapalı kısım taç kapısının ise 1-2-3 ve 5 . bordürleri kompozisyon derz ilişkisi içerisinde yapılmıştır. Bu kompozisyonların tamamı da yine tek eksenli sonsuz karakterlidir ve kompozisyonların yükseklikleri kesme taş yüksekliğine göre yer yer değişmektedir (Görsel 6).

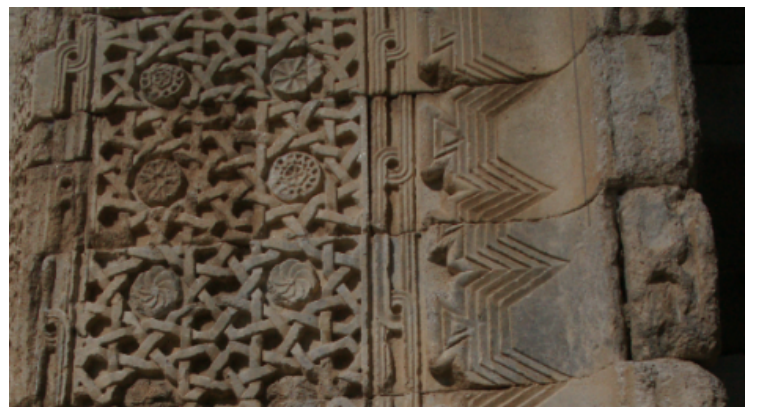

Görsel 6. Aksaray Sultan Hanı kapalı kısım taç kapısı kompozisyon-derz ilişsisi içerisinde yapılan 12-3 ve 5. bordürler

Ağzıkara Han (1231-40) avlu taç kapısının ana bordürü ile birlikte birinci ve ikinci bordürü de kompozisyon-derz ilişkisi dâhilinde yapılmıştır. Ancak ana bordürün 1,03 m. eninde olması ve kare bir kompozisyon olması nedeniyle kompozisyon-derz ilişkisi ana bordürde yarım, birinci bordürde bir, ikinci bordürde ise 1,5 kompozisyon olarak düzenlenmiştir. Kapalı kısım taç kapısında taş yükseklikleri eşit olmamakla birlikte; birinci, ikinci ve dördüncü bordürler kompozisyon-derz ilişkisi içerisinde yapılmışlardır. $\mathrm{Bu}$ üç bordürün de tek eksenli sonsuz karakterli kompozisyon olması nedeniyle düşeydeki çizgilerin biraz kısa veya uzun yapılması neticesinde kompozisyon-derz ilişkisi bozulmamıştır. Sivri kemerli tonozun kemer taşlarının da aynı ilişki içerisinde yapıldığı görülmektedir.

Zazadin Han (1235-36) avlu taç kapısının da kesme taş yükseklikleri aynı olmamasına rağmen 1-2 ve 4. tek eksenli sonsuz karakterli bordürlerinin kompozisyon-derz ilişkisiyle yapıldığı görülmektedir.

Eğirdir Han (1237-38) taç kapısı ana bordüründeki kompozisyon dikine dikdörtgen olan şeklinden dolayı blok taşlara yarım şekliyle işlenerek bu ilişki sürdürülmüştür. Ancak taç kapının üst bölümlerinde yükseklikleri daha az olan taş bloklar kullanılması nedeniyle bu ilişkinin bozulduğu görülmektedir. 
Pazar Hatun Han (1238) avlu taç kapısı ana bordürü ilk üç sıra dışında kompozisyon-derz ilişkisi içerisinde yapılmıştır. Üçüncü sıra ile dördüncü sıra taş blokların kompozisyon birleşimi ise düzensizdir. Sivri kemerli tonozun kemer taşlarının da aynı ilişki içerisinde yapıldığı görülmektedir.

İncir Han (1239-40) kapalı kısım taç kapısının birinci bordürü ve istiridye formlu sivri kemerinin alınlığındaki süsleme, Karatay Han (1240) kapalı kısım taç kapısının 1 ve 2. bordürleri ile sivri kemerli tonozun kemer taşları, Konya Sırçalı Medrese (1242) taç kapısının sivri kemerli tonozunun kemer taşları, İshaklı Han (1249) avlu taç kapısının tek bordürü, Kayseri Hacı Kılıç Medresesi (1249) taç kapısının birinci bordürü ve mukarnas frizi, Avanos Sarı Han (1249) kapalı kısım taç kapısının ikinci bordürü, Konya Karatay Medresesi (1251) taç kapısının iki kanadındaki renkli taş malzemeyle yapılan süsleme panoları ve Denizli Ak Han avlu taç kapısı sivri kemerli tonozun kemer taşları kompozisyonderz ilişkisi içerisinde yapılmışlardır.

Amasya Gök Medrese Camii (1266-67) türbesinin giriş kapısı bordürleri ile pencere kenarındaki geometrik kompozisyonların tamamında kompozisyon-derz ilişkisi bulunmaktadır. Yapının taç kapısının kanatlardaki birer bordürünün ilk iki taş sırası ve pencerelerden birinin köşe sütuncelerinin ilk taş sırası kompozisyonlar işlenmeden boş bırakılmıştır. Taç kapı bordürlerindeki boşluğun, kaide bölümüne denk gelmesi nedeniyle farklı yükseklikte taş kullanılmasına bağlanabilir. Pencere sütuncelerindeki bölümlerin ise büyük bölümünü kaidelerin kapladığı, üstte de küçük bir alanın kalması nedeniyle ayrıca ilgilenilmediği düşünülebilir.

Kayseri Sahibiye Medresesi (1268) taç kapısının alt bölümü, oluşan tahribat nedeniyle restorasyona tabi tutulmuştur. Belirli bir yükseltiden sonra da kompozisyon-derz ilişkisi geometrik süslemeli ana bordürde değil, bitkisel süslemeli dıştaki bordürde uygulanmıştır. Zikzak düzenlemeli dış bölümdeki köşe sütunları da kompozisyon-derz ilişkisi içerisinde yapılmıştır. Kompozisyonun taş yüzeyine çizimi sırasında şablonun ters tutulması neticesinde oluşmuş bitkisel süslemeli bordürün taş birleşimlerinde bazı hatalar tespit edilmiştir (Görsel 7). Kompozisyon-derz ilişkisi gözetilmeden yine yerde yapıldığ1 düşünülen birinci bordür olan mukarnas frizi ve üçüncü bordür olan geometrik süsleme bordürü taşlarının birleşim noktalarının bir bölümü hatalıdır. Geometrik süslemeli bordürde de yine şablonun ters düzenlenmesi sonucu hatalı oymalar meydana gelmiştir.

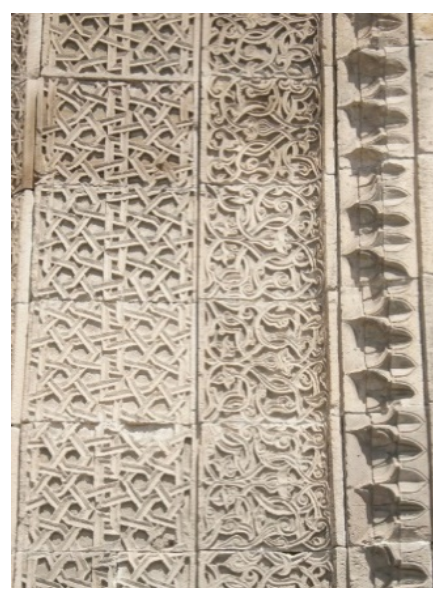

Görsel 7. Kayseri Sahibiye Medresesi taç kapısındaki kompozisyon-derz ilişkisinde yapılmış bitkisel süslemeli bordür. Mukarnas frizi ve geometrik süslemeli bordürün birleşim noktalarında kompozisyonlarda yer yer aksakllklar görülmektedir.

Buruciye Medresesi (1271) taç kapısındaki ana bordür ve birinci bordür bitkisel süslemelidir ve taç kapının yarısına kadar olan bölümde kompozisyon-derz ilişkisi uygulanmıştır. Üst bölümde taş ölçüleri değişmiş ve bu uygulamaya devam edilmemiştir. 
Sivas Çifte Minareli Medrese (1271) taç kapısında mukarnas frizi, Sivas Gök Medrese (1271) taç kapısının geometrik süslemeli ana bordürünün iç tarafındaki bitkisel kompozisyona sahip bordür (Görsel 8) ve Erzurum Çifte Minareli Medrese (1285-90) (Karamağaralı, 1971, s. 233) taç kapısındaki yine iki bitkisel bordür kompozisyon-derz ilişkisi içerisinde yapılmıştır (Görsel 9).

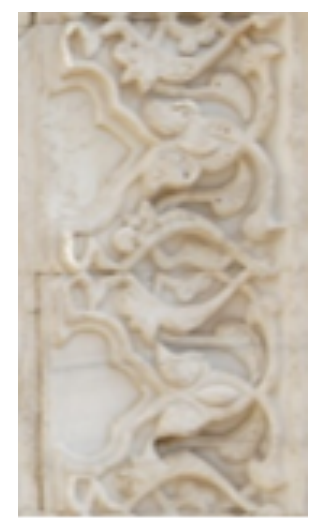

Görsel 8. Sivas Gök Medrese taç kapısındaki kompozisyon-derz ilişkisinde yapılmış bordür

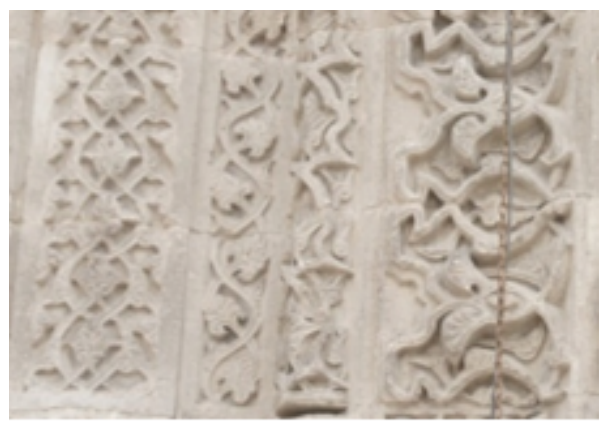

Görsel 9. Erzurum Çifte Minareli Medrese taç kapısındaki kompozisyon-derz ilişkisinde yapılmış iki bordür

Beyşehir Eşrefoğlu Camii (1299) taç kapısındaki bitkisel süslemeli ana bordür ve Amasya Şifahanesi (1308) taç kapısında en dıştaki sekizgen süslemelere sahip kaval silme ile birinci bordürdeki bitkisel süsleme şeridi kompozisyon-derz ilişkisi içerisinde yapılmıştır.

$\mathrm{Bu}$ yapılar dışında Ahlat yapılarında da kompozisyon-derz ilişkisi rahatlıkla görülmektedir. Selçuklu üslubunda inşâ ettirilen Hüseyin Timur Türbesi (1280), Buğatay Aka Türbesi (1281), Usta Şagird Türbesi (1285 civarı) (Karamağaralı, 1971, s. 239) ve Hasan Padişah Türbesi’nde (1275) gövdeyi düşeyde eş parçalara bölen ve diğer kompozisyonlara göre daha büyük ölçekli tasarlanan tek eksenli sonsuz karakterli kompozisyonlar yine bu ilişki içerisinde yapılmışlardır. Gövde üzerindeki silmelere göre daha küçük ölçekli kompozisyonlara sahip olan kapı ve pencere etrafındaki kompozisyonların bir kısmının da yine aynı anlayışla yapıldığı söylenebilir.

\section{Sonuç}

Anadolu Selçuklu dönemine ait incelenen yapılardan kompozisyon-derz ilişkisi tespit edilen 34 yapı bulunmaktadır. Bu ilişki bazı yapılarda sadece ana bordür üzerinden hareket edilerek kurulurken, Amasya Hilafet Gazi Türbesi (1210), İzzeddin Keykavus Şifahanesi (1217-18), Niğde Alâeddin Camii (1223) kuzey, Divriği Ulu Camii (1228) doğu, Karatay Han (1240 ) kapalı kısım, Hacı Kılıç Medresesi (1249), Kayseri Sahibiye Medresesi (1268), Buruciye Medresesi (1271), Erzurum Çifte Minareli Medrese (1285-90), Amasya Şifahanesi (1308) taç kapılarında iki, Alay Han, (1228) Aksaray Sultan Hanı (1229) avlu, Ağzıkara Han (1231-37) avlu ve kapalı kısım, Zazadin Han (1236-37) avlu taç 
kapılarında üç, Niğde Alaaddin Camii (1223) ve Aksaray Sultan Hanı kapalı kısım taç kapılarında ise dört bordür dâhilinde kurulabilmektedir. Bazı yapılarda ise sadece sivri kemerli tonozların kemer taşlarında söz konusu ilişki görülebilmektedir (Görsel 10).

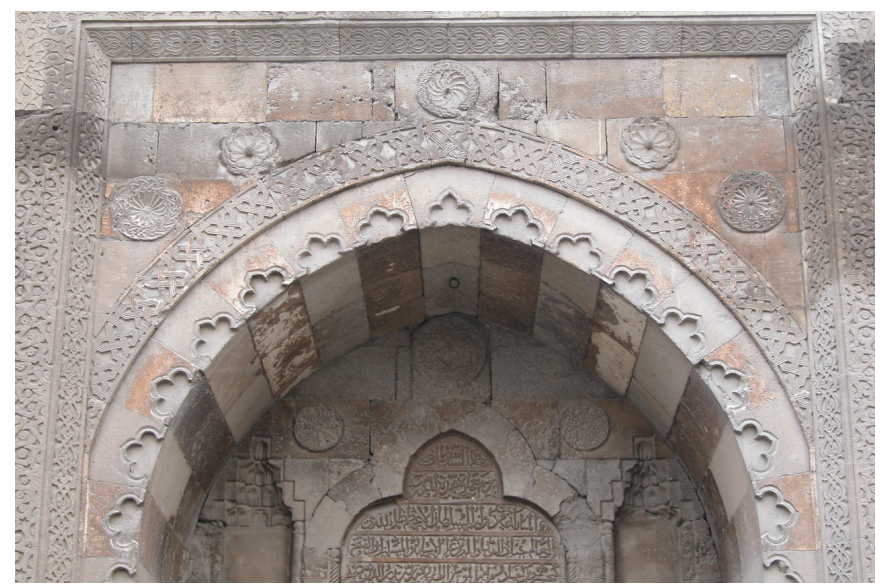

Görsel 10. Konya Sırçalı Medrese Taç kapısı sivri kemerli tonoz bölümündeki kompozisyon-derz ilişkisi

Kompozisyon-derz ilişkisi içerisinde yapılan ana bordürlerde, örgü taşlarının düşeydeki derzleri az sayıdaki yapı dışında kompozisyon ortasında verilmemiştir. Sivas İzzettin Keykavus Şifahanesi (121718) taç kapısında ise düzenli olarak bordür ortasında ve kompozisyon-derz ilişkisi dâhilinde yapılmıştır. Divriği Kale Camii'nde (1180) kare şeklindeki örgü taşlarına işlenen kompozisyonlar, bu haliyle taç kapıyı çevrelemiş, bordür taşları yanlardaki örgü taşlarıyla şaşırtmalı yapılamamıştır. Tercan Mama Hatun Türbesi (1192-1202) ve Amasya Hilafet Gazi Türbesi (1210) ana bordürlerinde ise küçük çıkıntılarla şaşırtmalı örgü gerçekleştirilebilmiştir. Kayseri Çifte Medrese (1205), Evdir Han (1215-19) ve daha sonra yapılan yapılarda ise ana bordürün yandaki bölümlerle bağlantısı daha iyi sağlanmış, şaşırtmalı örgü düşeydeki derzlerin alttaki ve üstteki taşların yaklaşık ortalarına gelecek şekilde yapılarak ya da enleri 2 metreyi bulan kesme taşlar kullanılarak daha sağlam bir tekniğe ulaşılmıştır.

Anadolu Selçuklu taç kapıları ana bordürlerinde 13. yüzyılın ilk yarısında geometrik kompozisyonlar kullanılmıştır. İlk defa bitkisel bordürün kompozisyon-derz ilişkisiyle yapılması Divriği Ulu Camii doğu taç kapısı üzerindeki bordürde gerçekleşmiştir. Divriği Ulu Camii’nin dönemi açısından ünik bir örnek olduğu ve bu taç kapının tarihlendirmesine dair farklı görüşlerin bulunduğu düşünülürse (Kuban, 1999, s. 133) bu sistemin Kayseri Sahibiye Medresesi (1268) taç kapısındaki bitkisel kompozisyonda görüldüğü söylenebilir.

Kompozisyon-derz ilişkisi Anadolu Selçuklu sanatında bir yapı tekniğidir ve bazı konulara dair bariz ipuçları vermektedir. Anadolu Selçuklu yapılarında önce yapının, sonrasında tezyinatın yapıldığı ya da önce tezyinatın taşlara işlenip sonra yapının oluşturulduğuna dair farklı görüşler savunulmaktadır.

Haluk Karamağaralı "Selçukluların ve onları takip eden devirlerin yapılarında tezyinat ve kitabeler yerde değil; örgü ve kaplama tamamlandıktan sonra doğrudan doğruya yerinde işlenmektedir" demektedir. Bu görüşünü de Erzurum Çifte Minareli Medrese ve Bursa Yeşil Camii' deki yarım kalmış tezyinatı örnek vererek desteklemeye çalışır (Karamağaralı, 1971, s. 211). Şüphesiz verdiği örneklerdeki kompozisyonların tamamı yapı üzerinde işlendiğinden yarım kalmıştır.

O. Cezmi Tuncer ise süslemenin yerde yapılıp yapıya yerleştirildiğini, yarım kalan yapıların büyük çoğunluğunun siyasi ve ekonomik çalkantıların olduğu Moğol istilasından sonraki döneme denk geldiğini belirtmektedir. Bu kanaate de 33 yıllık şantiye deneyimiyle vardığını özellikle belirtir (Tuncer, 1990, s. 236). "Bezenmiş taşların sınıflandırılması" (Tuncer, 1990, s. 233) başlığı altında verilen 
maddelerdeki özelliklerin süslemelerin yerde yapıldığ 1 yapılarda kullanıldığ 1 bir gerçektir. Ancak bu özelliklerin olmadığı yapıların da süslemelerinin üzerinde işlendiğini düşünmek gerekmektedir.

Yıldıray Özbek bu teknikleri kabul etmekle beraber üçüncü bir seçenek olarak "süslemenin bina ile aynı anda yapıldı̆̆ı" tezini ileri sürmektedir. Tezini de Ahlat Yarım Kümbet'in kaide üzerinde 1,5 m. yüksekliğe kadarki bölümünün tamamının süslemesinin yapılmasını örnek vererek destekler (Özbek, 2002, s. 32). Bu dönemdeki Ahlat yapılarının tamamı kompozisyon-derz ilişkisi içerisinde yapılmışlardır. Dolayısıyla "bina ile aynı anda yapıldığı" tezinin yerine, yerde taşların işlenip akabinde yapıya yerleştirilmesi tekniğinin kompozisyon-derz ilişkisinin izlenebildiği Ahlat Yarım Kümbet’te (13. yüzyıl ikinci yarısı) (Tabak, 1972, s. 23) de uygulandığı rahatlıkla söylenebilir.

Ayla Ödekan, yüzeysel bezemelerin yapı tamamlandıktan sonra yapılmalarının akla daha uygun olduğunu, ancak üç boyutta tasarlanan ve karmaşık geometrik şemalar içeren bölümlerin yerde yapıldığını düşünmektedir (Ödekan, 1977, s. 114).

Anadolu Selçuklu yapı tekniği düşünüldüğünde yapının ya da süslemenin önce yapılışının inisiyatifi tamamen yapının mimarında olmalıdır. Başka bir deyişle mimarın yetişmiş olduğu ekolün bir yansıması, bir tercihidir. Anadolu Selçuklu yapılarında süslemeler ağırlıklı olarak taç kapılara yapılmaktadır. Bu sebeple taç kapılar üzerinden gidilirse; kompozisyon-derz ilişkisinin olduğu 34 Anadolu Selçuklu yapısından, iki eksenli sonsuz karakterli geometrik kompozisyonlar (ana bordürler) arasında bu ilişkinin izlenebildiği bordürlerin tamamında (Eğirdir Han ve Buruciye Medresesi taç kapılarında bu ilişki sınırlıdır) örgü taşlarına süslemelerinin yapıldığı, bilahare taç kapının oluşturulduğu rahatlıkla söylenebilir. Bu durum, her taşa aynı kompozisyon işleneceğinden, daha fazla kişinin aynı anda ayrı taşlar üzerinde çalışması şeklindeki seri üretim mantığıyla da açıklanabilir.

Taç kapıyı çevreleyen geometrik bordürlerdeki kompozisyonların en azından bir kısmının taç kapı tasarımında belirlenmesi ve onlara göre taç kapının yükseklik ve bordür kalınlığının ayarlanması gerekmektedir. "Bu durumun bir başka kanıtı da taş ocaklarından kesilen taşın yüksekliğinin kompozisyon yüksekliğiyle aynı olmasıdır. Bordürlerde kompozisyonlardaki aksamanın sebebi ise "çerçeveyle desenin ritminin uyumunun başta sağlanamamasıdır" (Tuncer, 1990, s. 231-232). Tasarımda kompozisyonların belirlenmesi zorlu bir tasarım sürecine işaret etse de basit oran-orantı hesaplamalarıyla kolaylıkla yapılabilecek bir yöntem olduğu açıktır. Örneğin kompozisyon-derz ilişkisi dört bordürü kapsayan Niğde Alaaddin Camii (1223) taç kapısında ana bordürdeki bir kompozisyona, birinci ve ikinci bordürden iki, dördüncü bordürden ise yine bir kompozisyon, Alay Han taç kapısında ise ana bordür kompozisyonuna yandaki küçük bordürde üç kompozisyon denk gelmektedir.

Anadolu Selçuklu taç kapılarında ana bordürlerde kompozisyonların bazıları düzensizdir. Ana bordürde iki farklı kompozisyonun kullanıldığı Hacı Ferruh Mescidi (1215) ve Niğde Alaaddin Camii (1223) taç kapıları, kompozisyonu çoğaltılma sınırları dâhilinde verilmeyen Amasya Hilafet Gazi Türbesi (1210) taç kapısı ve bitkisel süslemeli şablonun çizim aşamasında muhtemelen ters tutulmasından kaynaklanan palmetlerin farklı yönlerde yapıldığı Kayseri Sahibiye Medresesi (1268) taç kapıları kompozisyon-derz ilişkisi içerisinde yapılmışlardır ve bahsedilen düzensizliklere sahiptirler. Kayseri Sahibiye Medresesi'nde (1268) kavsara kemeri ve içindeki altıgen süslemelerin tasarımı düşünüldügünde de yapının genel bir düzensizliğinin olduğu söylenebilir. Divriği Ulu Camii doğu taç kapısında kompozisyon-derz ilişkisi iki bordür üzerinden gerçekleştirilmiştir. Ancak birinci bordürle ikinci bordürün arasında, birinci bordür kompozisyon kalınlığı kadar mesafe bırakılmadığı için bırakılan mesafe kadar bir süslemeli parça bitkisel bordüre eklenmek zorunda kalınmıştır. (Görsel 11) Benzer şekildeki tasarım hataları bu tekniğin en büyük sorunu olarak görülmektedir. 


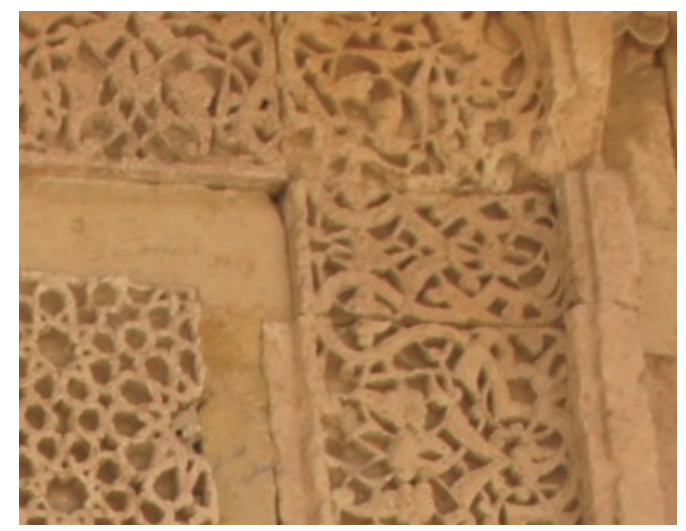

Görsel 11. Divriği Ulu Camii doğu taç kapısı bitkisel bordüründeki farklı tasarım dikkati çekmektedir

Bahse konu 34 yapı dışındaki Anadolu Selçuklu taç kapılarında kompozisyon-derz ilişkisi süsleme kuşakları dâhilinde bulunmamaktadır. Bununla birlikte kompozisyonlarda da şablonun ters tutulması ve uygulama hataları (Bulut, 2017, s. 40) dışında benzer düzensizliklere rastlanılmamaktadır. Kayseri Sahibiye Medresesi taç kapısı bitkisel süslemeli bordürde ve Denizli Ak Han avlu taç kapısı ana bordüründe şoblonun ters tutulmasından kaynaklı çok sayıda hata tespit edilmiştir. Denizli Ak Han avlu taç kapısı ana bordüründeki düzensizliğin onarım sonucu oluştuğu belirtilmişse de (Dursun, 2017, s. 155) çizgi sistemlerinin atlamalı yapılışında kesme taşlar arasındaki düzensizlik daha çok şablonun ters kullanılmasına bağlanabilir. Süslemenin oluşturulacağı bölümün tamamlanmasının ardından şablonlardaki kompozisyonların bordürlere çizilmesinde ve bordürlerin oyulmasında hata olma ihtimali çok azdır. Dolayısıyla düzensiz olan bordürlerin taşlarının önce süslemesinin yapılması, sonrasında da yapıya yerleştirilmiş olması akla daha yatkın gelmektedir. Bu nedenle de kompozisyon-derz ilişkisinin bulunmadığı, dolayısıyla da bazı uygulamalarının standardize edilmediği yapıların süslemelerinin yapı üzerinde oluş̧turulduğu düşünülebilir. O. Cezmi Tuncer bezenmiş taşların sınıflamasını; "bazı renkli taş işçiliğinin görüldüğü bölümler ve geçmeli kemerler, bezeli veya yonulu tek taşlar, taşın boyuyla bezeme bağı olanlar ve el ve aletin işleyemeyeceği durumlar" başlıkları altında değerlendirmiştir (Tuncer, 1990, s. 233). Bu bölümlerdeki kompozisyonların önce taşa işlendiği, ardından da yapıya monte edildiği şüphesizdir. Ayrıca Anadolu Selçuklu taç kapılarında rozetlerin her zaman yekpare bir kesme taşa oyulduğu düşünüldüğünde (Beyşehir Eşrefoğlu Camii taç kapısındaki rozet bu konudaki tek istisnadır) kompozisyon-derz ilişkisinin az da olsa kullanılmadığı yapının olmadığı görülebilir. Bahse konu başlıkların tamamı yapıda tespit edilebilen, belirtileri izlenebilen konulardır.

Anadolu Selçuklu sanatında yapıların bu iki teknikle yapıldığı, süslemenin öncelikli taş üzerinde yapılıp yapıya sonradan monte edildiği tekniğin 1180-1229 yılları arasında yapılan yapıların tamamında ana bordürler üzerinde kullanıldığg görülmektedir. Bu tarihten sonra ise bu ilişki daha çok ana bordürler dışındaki diğer bordürler üzerinden sağlanmıştır.

Kompozisyon-derz ilişkisinin ana bordürler üzerinde görüldüğü yapılar incelendiğinde; bu yapılarda güney etkisi dediğimiz özellikteki unsurlara (zikzak düzenlemeli köşe sütunceleri (Eser, 2006, s. 69), diş sırası şeklindeki süsleme unsuru, Zengi düğümü, yatık U şeklindeki sütunce kaidesi ve burmalı köşe sütunları (Bilici, 1989, s. 45-49), istiridye formları (Beksaç, 1995, s. 239) genellikle rastlanılmadığ1 dikkati çekmektedir. Anadolu Selçuklu öncesi Anadolu yapılarında da bu tekniğin kullanıldığına dair bir iz tespit edilememiştir. Kompozisyon-derz ilişkisi dâhilinde inşa edilen yapıların da Marend, Meraga ve Ahlatlı mimarlar olması dikkat ekicidir. Dolayısıyla kompozisyon-derz ilişkisini, taş malzeme ile yeni tanışan Anadolu Selçuklu sanatçısının yapıları oluştururken tecrübe ettiği yeni bir teknik olarak değerlendirmek doğru olacaktır. 


\section{Kaynakça}

Bakırer, Ö. (1969). Hacı Ferruh Mescidi. Vaknflar Dergisi, 8, 171-184.

Beksaç, E. (1995). Fatımiler. DIA, 12, 238-240.

Bilici, Z. K. (1989). Antalya müzesi’ndeki bir Selçuklu kitabesi üzerine düşünceler. Antalya 3. Selçuklu Semineri Bildiriler Kitabı (s. 45-49) içinde. İstanbul.

Bulut, M. (2017). Geometrik sistemin çözümlenmesi Selçuklu örnekleri üzerine birkaç girişim. Sanat Tarihi Dergisi, 26 (1), 27-44.

Dursun, Ş. (2017). Denizli Ak Han'ın avlu taç kapısına ilişkin bazı gözlemler. VIII. Uluslararası Türk Sanatı, Tarihi ve Folkloru Kongresi/Sanat Etkinlikleri Bildiriler Kitabı (s. 149-158) içinde. Konya.

Eser, E. (2006). Anadolu Suriye sanat ilişkileri. A. Y. Ocak, A. U. Peker ve K. Bilici (Ed.), Anadolu Selçukluları ve Beylikler Dönemi Uygarlığı 2 (s. 67-74) içinde. Ankara: Kültür ve Turizm Bakanlığı Yayınları.

Karamağaralı, H. (1971). Erzurumdaki Hatuniye Medresesinin tarihi ve banisi hakkında bazı mülahazalar. Selçuklu Araştırmaları Dergisi III, Malazgirt Zaferi Özel Sayısı, 209-247.

Kuban, D. (1999). Divriği mucizesi, Selçuklular çă̆ında İslâm bezeme sanatı üzerine bir deneme. İstanbul: Yapı Kredi Kültür Sanat Yayınc1lık.

Kuban, D. (2010). Cennetin Kapılart-Gates of Paradise. İstanbul: YEM Yayınları.

Mülayim, S. (1982). Anadolu Türk mimarisinde geometrik süslemeler Selçuklu çağı. Ankara: Kültür ve Turizm Bakanlığı Yayınları.

Ödekan, A. (1977). Osmanlı öncesi Anadolu Türk mimarisinde Mukarnaslı portal örtüleri. İstanbul: İTÜ Mimarlık Fakültesi Yayınları.

Ögel, S. (1966). Anadolu Selçukluları'nın taş tezyinatı. Ankara: Türk Tarih Kurumu Yayınları.

Önge, Y. (1978). Divriği Ulu Camii ve Darüşşifası. Ankara: Vakıflar Genel Müdürlüğü Yayınları.

Özbek, Y. (2002). Osmanlı Beyliği mimarisinde taşs süsleme (1300-1453). Ankara: Kültür Bakanlığ1 Yayınları.

Tabak, N. (1972). Ahlat Türk mimarisi. İstanbul: Doğan Kardeş Matbaac1lık.

Tuncer, O. C. (1990). Taşın bezeme şekli üzerine düşünceler. VII. Vakıf Haftası (s. 231-246) içinde. Ankara: Vakıflar Genel Müdürlüğü Yayınları. 